\title{
LEGAL INFORMATION: THE LONG PATH AND THE WAY HOME
}

\begin{abstract}
Ahti Saarenpää
Abstract: In this article, I will be taking a look at the principles which should be made the foundation of legal information on statutes and its skilled use in the digital environment of the modern constitutional state. The issue goes beyond stating the obvious - that every digital lawyer in this day and age is capable of retrieving legal information in digital form from a digital datastore. There is another dimension too: we must have the expertise required to assess matters in terms of the information processes involved and the path the information will travel in the course of those processes.
\end{abstract}

\section{Table of contents}

1. Introduction..................................................................................................................

2. The information path.................................................................................................

3. Our Informational Environment and Akoma Ntoso.........................................................84

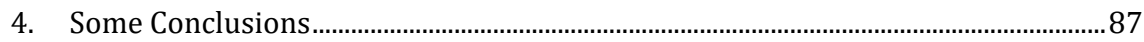

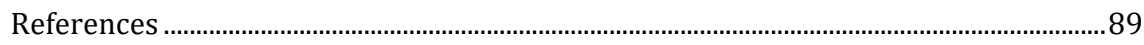

\section{INTRODUCTION}

At their simplest, laws generally present themselves to us as texts and signs. Both have long histories. And we should not forget the various images and symbols associated with law. Visual art sometimes tells us quite a bit in fact about law as well as concepts related - or once related - to it. As JULIA SHAW insightfully notes, images and sculptures 
are unwritten history. ${ }^{1}$ This, too, is something a well-educated lawyer should be aware of.

Statutory texts are also interpreted in other texts - legal literature and legal case law. I have often called lawyers «text eaters». ${ }^{2}$ It is our job to forage for texts, guided and bound as we are by the doctrine of legal sources and doctrines of interpretation. Nothing too much, nothing too little. And it is well known that law is an information-rich science.

Often our practical legal work begins by perusing the text of the law. And often this is the point where our information search ends as well - sad to say. ${ }^{3}$ This being the case, the various collections of statutes, which we consult primarily to find laws, have been and continue to be the informational pillars of our work; they are information stores. In contrast to most other social sciences, law has little or no choice when it comes to using statute-level information. Legal dogmatics in particular is naturally bound to the body of laws in force at any given time. And these must be published. There are nowadays many ways to do that.

Yet statutes are no more than stopping-off points on the more and more expansive path of legal information. Statutes are interpreted and interpreted again. This has been the practice for a very long time. The process is among the fundamental conditions for the existence of the legal profession. Not surprisingly then, the written history of law is largely a history of interpreting laws and skills in doing so.

1 SHAW gave her review of PETER Goodrich's Legal Emblems and the Art of Law: Obiter depicta as the Vision of Governance using the title «Worth a Thousand Words: The Unwritten History of Law as a Jurisprudence of Text and Pictures».

2 The Finnish book Tekstinsyöjät [lit. Text-eaters], published in 1991, by LUOSTARINEN and VÄLIVERRONEN describes the particular form of literacy associated with research in the social sciences. Law, as a social science, is at the core of such text eating. Our discipline guides how we read more strictly than in other social sciences. I should point out that today both of the authors are professors of communication.

3 In Finland professor KAUKO WIKSTRÖM has written about «open the law-book» theory of the sources of law. That is often one reason why we sometimes see a guiding toward the scarcity of law. 
In today's digital constitutional state, legal information and its weight must be viewed first and foremost in terms of information processes. Traditional static documents are but a ghosts of days past. We live and work in a digital environment «plugged into» dynamic information systems. The quality standards set for information processes in the digital network society are an essential element in guaranteeing that legal life functions at least on an acceptable level. 4

Doing research on and teaching information retrieval have been among the first focal areas in the birth and development of legal informatics almost everywhere. In the Nordic countries - PETER SEIPEL in Sweden and JON BING in Norway - were the first to elaborate the key stages in what competence in retrieving information entails. ${ }^{5}$ For both, the question was more than one of how programs handled textual information retrieval. ${ }^{6}$ For his part, Peter Blume, in Denmark, continued this work not only in his thesis on the development of legal information - from speech to data - but above all on determining the role of information in the lawyer's methodological competence. For Blume, information retrieval is part of the doctrine of legal sources. ${ }^{7}$ This view is easy to endorse. It embodies what is a shared Nordic conception of the significance of legal information in legal life. In this context I must point out, that written law has very much been our point of departure in the Nordic countries.

While I will not go into greater detail on the history of information retrieval, I must mention another doctoral dissertation here, one which JON BING followed closely and

4 See more for example Dingledy From Stele to Silicon: Publication of Statutes, Public Access to the Law, and the Uniform Electronic Legal Material Act in Law Library Journal Vol. 111:2 [2019-9]. In USA the Uniform legal Material Act (UELMA) as a guiding framework was drafted 2011. And as DINGLEDY has written: «As of March 2019,19 states and the District of Columbia have passed UELMA, and 3 more state legislatures have introduced legislation to enact it.».

5 In SEIPEL'S Legal Informatics textbook, several editions of which have been published, information retrieval has in fact figured prominently. BING's dissertation, now a classic work, was based on the importance of legal information retrieval. See SEIPEL Juristen och datorn: introduktion till rättsinformatiken Norstedts 1990. 3. ed and BING Rettslige kommunikasjonsprosesser: bidrag till en generell teori.

6 GRAHAM GREENLEAF provides a singular description of Bing's importance in his article Jon Bing and the History of Computerised Legal Research - Some Missing Links. passim.

$7 \quad$ See Blume Retssystemet og Juridisk Metode 3 ed 2016. (in Danish) 
supported. This was ERICH SCHWEIGHOFER's thesis. When he finished it in 1996, the research provided its readers with a distinctly more detailed perspective on competence in legal information retrieval and the limits on retrieval. ${ }^{8}$ In keeping with the development of IT at the time, he included, on page 210, a brief treatment of the role of hypertext, too. The work is still well worth reading as a window offering insights into legal information retrieval in the early days.

Research and teaching on information retrieval are important today as well. Many of the fundamentals have either not changed or have increased in importance. Legal information is a far more important type of raw material than ordinary information.

As it develops, the constitutional state necessarily imposes its own, increasingly specific constraints on the creation, processing and use of legal information. I have put forward the following as what I consider the core principles of legal information: ${ }^{9}$

(1) comprehensive accessibility of official materials

(2) accuracy of the information

(3) locatability of the information in time and place

(4) retrievability of the information from data bases

(5) linguistic and systematic comprehensibility of the information

(6) technical usability of the material in the work of the person retrieving it

(7) the extent to which the material is available free of charge

(8) interoperability; structural, semantic and technical ${ }^{10}$

8 SCHWEIGHOFER, ERICH, Wissensrepräsentation und automatische Textanalyse im Völker- und Europarecht, Habilitationsschrift, Universität Wien 1996; in English later Legal Knowledge Representation, Automatic Text Analysis in Public International and European Law, Kluwer Law International, Law and Electronic Commerce, Volume 7, The Hague (1999).

9 SAARENPÄÄ The Network Society and Legal Information. Some observations from the Nordic point of view p. 15. Law via the Internet conference papers Hong Kong 2011.

10 Interoperability is, as Dr TUOMAS PöYSTI has personally remarked, the main framework of this paper. 
Each of these is important. Needless to say, they must be assessed in the light of the development of the constitutional state. And in today's digital environment they must all be fine-tuned to accommodate the evolving path information travels with all of the associated opportunities and risks.

\section{THE INFORMATION PATH}

«Information path» as a concept has established itself as a in information science in Finland. It is the title of an edited volume, now in its eleventh edition, that has been used as an introductory text in the teaching of information sciences. The topics taken up in the work range from document management to archiving. ${ }^{11}$

The notion of information travelling a path is important in legal perspective; in fact, it embodies an essential insight into the significance of legal information as part of the legal culture and lawyers» professional skills. The long path information takes in our society spans a gamut from technological choices to the possibilities of and restrictions on the recycling of information. In the modern constitutional state, each of the stages on this path must proceed with due regard for human and fundamental rights.

This is not a simple undertaking. The risks that cause a scarcity of justice are increasing. The traditional era of static documents in the old-fashioned paper format or technical data base systems, a relatively tractable one in legal terms, is now over. We have entered the era of digital rights in the digital environment, one in which the path of information from beginning to end will always call for legal scrutiny.

A good example of the problems related to planning the path information takes is public access to official documents. In keeping an eye with the principle of public access, traditional documents, particularly in the Nordic countries, have been classified as either public or secret. When working on information systems, this distinction has been difficult to maintain rigorously. Above all, in the light of data protection legislation, the key

11 MÄKINEN ILKKA (ed) Tiedon tie; johdatus informaatiotutkimukseen, 11 ed (2011). MR MäKINEN'S $\mathrm{PhD}$ dissertation was on the development of lending libraries in Finland. This topic is significant when assessing the path information travels. 
issue is what kind of information may be placed in what situation in various types of printouts. ${ }^{12}$ In the case of GDPR, the varied laws on public access and the varied legal cultures of the Member States remained - had to be left - strictly unregulated. Article 86 is like a loaded gun without the safety catch. Such catch should and could be systematics. ${ }^{13}$ With this decision, planning the path of information became even more difficult. ${ }^{14}$ Specialized data protection lawyers and specialized public and procedural law lawyers have difficulties to meet each others. An everyday constitutional right is a lot depending the slow legal machinery, where the practices of ECHR and the EU Court of Justice are playing the key roles.

If we want to be good lawyers, we must also know how to link the symbols and images to the correct informational environment. This is particularly important where legal dogmatics is concerned. The risk of applying and recommending the wrong provision due to incorrect or insufficient material is often considerable.

In this connection it is essential that we remember the diversity of legal cultures. The most pronounced difference has been that between common law and statutory law systems. Staying abreast of developments in case law has become ingrained far more deeply as an aspect of legal knowhow than, for example, keeping up with European statutory law. This difference has narrowed somewhat in Europe with the increasing significance of judgements by the Court of Justice of the European Union and European Court of Human Rights. These rulings are essential pointers on the path information takes, signs that we keep our eyes on most vigilantly. However, we still have lawyers who orientate in the domestic source material only.

As far back as the days of the Personal Data File Act, we had a special provision of the visibility of personal identity number in printouts: The controller shall see to it that the personal identity number is not unnecessarily included in hard copies printed or drawn up from the personal data file.

Article 86: «Personal data in official documents held by a public authority or a public body or a private body for the performance of a task carried out in the public interest may be disclosed by the authority or body in accordance with Union or Member State law to which the public authority or body is subject in order to reconcile public access to official documents with the right to the protection of personal data pursuant to this Regulation.»

14 The Deputy Data Protection Ombudsman in Finland, mrs ANU Talus, defended in november 2019 her dissertation on the relation between data protection and public access to official documents. See Talus From simply sharing the Cage to living together. 
An equally important observation is that communication in law requires a far more consistent system of concepts and references than in most fields. Where most social sciences may operate rather freely using proprietary concepts - redefining them as they go - law is bound to a well-established and consistent terminology. Indeed, the old German conceptual legal dogmatics (Begriffsjurisprudenz) was an effort to serve practicing lawyers through a system of consistent concepts and terms. Playing a similar role today is the legislative technique applied by the European Union. Directives and regulations have introduced a significant number of concepts and terms into legal life that serve to make our communication more consistent. ${ }^{15}$

Also crucial is the way in which we communicate through references. Where social sciences often content themselves with short in-text references, law, and particularly legal dogmatics, generally relies on footnotes. These give the reader information going beyond that in the text proper. As a matter of fact, the footnote has long been one of the most important manifestations of visual law. It provides an opportunity and at the same time imposes an obligation to augment an otherwise strictly linear text with important, immediately locatable information. ${ }^{16}$ Footnotes, too, are part of the path information takes. Sadly, in practice references are often considered a mere formality. Nothing could be farther from the truth if we choose to take legal communications seriously. When properly planned and written, footnotes enhance the reader's engagement with the text. ${ }^{17}$

When JON BING published his doctoral thesis, as well as the several information retrieval guides that followed, it was natural to draw attention to texts and their accuracy. For example, in Finland, our national legal data base Finlex went through a phase in the

15 For example, in the GDPR the general provisions contain 26 definitions and the Regulation's recitals and other different sections have many more important concepts. We can say, that the instrument has introduced a new data protection vocabulary.

16 As a matter of fact, the footnote has long been one of the most important manifestations of visual law. It provides an opportunity and at the same time imposes an obligation to augment an otherwise strictly linear text with important, immediately locatable information.

17 For example, a footnote with no more than the author's name and the year in which the work was published is generally insufficient and does little to help the reader. They are not reader-friendly. Unfortunately, such footnotes have increased in Finnish legal literature as well. 
1980 marked by a search for and correction of typographical errors. Errors were found even in the electronic texts of laws. 18

The next phase of development focused on mark-up languages. In other words, attention was turned to how information is attached to its computer platform. This saw the gradual emergence of the Legal XML standard, in fact standards. Swedish professor of legal informatics CECILIA MAGNUSSON SJÖBERG has been one of the more prominent experts on mark-up languages. As tools for managing metadata, mark-up languages figure crucially in the production of electronic legal information. ${ }^{19}$

I will not go into any detail here on the development and impact of Legal XML. ${ }^{20}$ That history is already an extensive one. It is time to go further, for we now find ourselves deep in the era of Akoma Ntoso XML. This is - or could be - a key step forward for legal information on the long road home it must travel.

\section{OUR INFORMATIONAL ENVIRONMENT AND AKOMA NTOSO}

One of the distinctive features of any science, but of law in particular, is the location in time of the environment we work in. Every time we set out to investigate something or to make decisions, we take a risk that the information we rely on is not up to date or sufficient - it may have factual or temporal shortcomings. ${ }^{21}$ And quite often it may contain intertextual phrases without any new messages. Our professional skills

18 The Ministry of Justice had some of its inspection done by a young teacher working in the Faculty of Law at the University of Lapland.

19 See, for example, MAGNUSSON SJÖBERG, XML as a tool for legal validity in a security context and earlier Critical Factors in Legal Document Management: A study of Standardised Markup Languages, passim.

It has to said here that at least in Finland the role of mark-up languages has remained largely obscure to lawyers on the ground in Finland.

21 In Finland the most famous example of a lack of broad education in the case of a professor of law was an article published in the early 1900s where the author confounded sociality and socialism. Today we can almost every day read texts where data protection and data security seek their right places in the text. Unfortunately! 
should include the ability to assess such risks and ensure that the information we use is acceptable.22 Yet is all too often the case that lawyers fail to do so, as information may be scattered in different sources, consolidated in different ways or accessing it may be difficult or hampered by financial constraints. Information is not easy to access. Another consideration is that the limitations of information retrieval and its users easily shut out perspectives. Akoma Ntoso can be one key to solve some of those roadblocks. ${ }^{23}$

The development curve of Akoma Ntoso has been an interesting one. The standard, originally devised primarily for information management of parliament systems in Africa, has, in a short time, expanded - and markedly so - to become a versatile mark-up system for legal information. Its use goes beyond particular parliaments. Nowadays even United Nations, European Commission and European Parliament are using it. ${ }^{24}$

Akoma Ntoso has responded to a clear social need in keeping with the development of the constitutional state. The solutions developed and adopted by different countries at different times for legal drafting management of legal information needed - and still do need - harmonisation. The road information takes is still very much a winding and bumpy one. And there are still a lot of cultural differences. This every one of us, as researchers, readily notices in whatever we do in our own countries and internationally. ${ }^{25}$ We do need common legal and societal metadata too.

22 In the Nordic countries, the risk perspective has been highlighted in legal informatics by PETER WAHLGREN in Sweden and TOBIAS MAHLER in Norway. For later work, see also SCHWEIGHOFER - PREISS Risikoanalyse im Recht - eine neue juristische Methodik? pp. 597-608.

23 See generally akomantoso.org pages.

24 See more for example PALMIRANI-VITALI Akoma-Ntoso for legal documents pp. 75-100 in SARTOR (etc eds) Legislative XML for the Semantic Web: Principles, Models, Standards for ... and PALMIRANI Akoma Ntoso for Making FAo Resolutions Accessible pp. 59-69 in PERUGinelLI - FARo Knowledge of The Law in The Big Data Age.(2019) and SchEFBECK (ed) Schwerpunkt Elektronische Rechtsetzung, Jusletter IT.weblaw/ch/issues/2019/IRIS.html 2019.

25 Thank's to his computational research has JENS FRANKENREITER been able to show, that in the EU court the French legal culture still dominates the court in some extent. See FrankENREITER Writing style and legal traditions pp. 153-191 in LIVERMORE-ROCKMORE Law as Data. See also MATTILA Comparative Legal Linguistics pp 35 and 139. 
Some years ago, in 2006, I wrote in the festschrift for PETER SEIPEL about the need to rethink our concept of what legislation should be like. In that paper I pointed to a need for interactive legislation that would replace traditional linear texts and, in the process, ensure the quality of the information involved. ${ }^{26}$

By interactive legislation I mean legislation in which the text and other images of the laws are accompanied by information on their background and broader context. The traditional abstract linear text of the law would at least in part be replaced by communication of a different kind. In other words, some of the information typically found today in the drafting material or even the legal literature would be presented with legislation in the form of text references that appear in the electronic collection of statutes. The user of the text could thus obtain additional information on the relevant points as they are made actively available in the information space. The legal superhighway from human rights to the interpretation of individual provisions and guidelines would be rendered more readily visible. ${ }^{27}$

I would assert that legal informatics is an observatory for human rights in the Network society, a society where information networks and information systems are not mere tools but a working and living environment for individuals and organisations. The fact that access to those networks and the resources on them has begun to be seen as a human right tells us something essential about the development of the Legal Network Society. It is precisely such considerations that lawyers are able to focus on when informed by a proper method in legal informatics. Today, the path information travels is an essential element of this assessment.

I dare say that Akoma Ntoso has in principle and technically brought JON BING's great vision of an integrated national legal information system closer to reality even at the

SAARENPÄÄ Towards legal information and legal knowledge: some basic issues in Finnish perspective. In the same volumebook ERICH SCHWEIGHOFER explores the same topic to a certain extent in his article, Computing Law: From Legal Information Systems to Dynamic Legal Electronic Commentaries.

27 SAARENPÄÄ The Network Society and Legal Information. Some observations from the Nordic point of view in http://www.hklii.hk/conference/paper/2D1.pdf. The paper was presented at the Law via the Internet Conference papers in Hong Kong in 2011. 
international level. ${ }^{28}$ In the process, the individual's right to legal information as a pillar of his or her self-determination is better taken into consideration than before. ${ }^{29}$

When science fiction writer and futurologist ISAAC AsIMOv delivered an address at the 7oth anniversary of the ABA Journal in 1984, he predicted that the balance of information - Waffengleichheit - would improve in trials with the development of legal data banks in the decades to come. ${ }^{30}$ This observation was right on the mark. We now live in an age where data banks are being used more extensively in legal life in different countries. With this development, opportunities for an improved balance of information in different legal relationships are increasing.

However, development has not been quite as simple as AsIMOV perhaps thought it would be. Just making the official, primary sources of law available to all has taken a surprisingly long time in different legal cultures. And the markets for secondary sources, which bring added value, often pose an obstacle to achieving a balance of information. Moreover, AsImOV failed to anticipate the impact of the spread of the constitutional state internationally. ${ }^{31}$ And of course he could not forecast the creation of Akoma Ntoso.

\section{SOME CONCLUSIONS}

I will preface these conclusions with a brief account of how the personal identity code has been dealt with in one decision of the Finnish Parliamentary Ombudsman. A citizen filed a complaint with the Ombudsman as the individual's and 34 others? personal identity codes had remained visible when a court asked for their views of the person to be

DORIS LIEBWALD has provided an illuminating treatment of Bing's thinking in her article On transparent law, good legislation and accessibility to legal information: Towards an integrated legal information system.

29 In my textbook Law of personality I have written about 5 basic pillars in the case of citizens» selfdetermination. These are (1) the right to internal freedom, (2) the right to external freedom, (3) the right to competence, (4) the right to power and (5) the right to know. See SAARENPÄÄ Henkilö- ja persoonallisuusoikeus pp 223 in NIEMI (ed) Oikeus tänään (2015) in Finnish.

30 Asimov The next seventy years for law and lawyers. American Bar Association Journal 71:57-59 (1985).

31 See SAARENPÄÄ Does Legal Informatics Have a Method in the New Network Society? p. 68. 
appointed as distributor of a decedent's estate. The complainant considered the procedure illegal. Identity codes should not be visible in this kind of communication. In a reply to the Ombudsman, the senior judge cited to, among other arguments, the fact that in 2004 the Supreme Court had issued a ruling stating that the a court's records in the court archive do not constitute a personal data field and that crossing out the personal identity codes in printouts from the information system would be inconvenient.

The Ombudsman pointed out that the Supreme Court ruling in question dated from the era of paper documents and the inconvenience of crossing out the personal identity codes on the printout was not sufficient reason to omit to do so. ${ }^{32}$ In addition, the Ombudsman drew the Ministry of Justice's attention to the fact that the 178-page manual on the use of the court information system did not contain a single mention of data protection legislation.

In my view, this case reflects quite well how specialization can bring unwanted results. The judge making decisions neither knew how to interpret the Supreme Court's ruling nor had much knowledge of data protection legislation. Moreover, information management services in the Ministry of Justice were caught unprepared to deal with incorrect use of the system. The path the information was on came to an abrupt end.

The long path of information, as I already wrote, in our modern society spans a gamut from technological choices to the possibilities of and restrictions on the recycling of information. In the modern constitutional state, each of the stages on this path must proceed with due regard for human and fundamental rights. This is not a simple undertaking. If we make good use of Akoma Ntoso with acceptable metadata and remain aware of the harmful consequences of excessive specialization, we can continue to make progress toward the constitutional state. This is one important tool to reduce some distractions in modern legal communication. ${ }^{33}$

32 In learning materials I have for years put forward the view that even in the paper environment the ruling was unlawful in its overlooking the concept of «logical document», which is central to personal data protection. 
It is crucial that we notice that with Akoma Ntoso, if one wishes, in planning a legal information system on can locate legal information naturally in the time and legal culture that it represents. That is more and more important even in digital archives.

Akoma Ntoso is not only a technical solution. This should be seen as an essential element of statutory texts and databases. The path information takes must be equipped with «traffic signs» ensuring accuracy. We must link the symbols and images to the correct informational environment too. And we must be ready to observe what is important in the new framework. ${ }^{34}$

Having come this point in the article, it is high time to take a look at ERICH SCHWEIGHOFER's extensive list of publications. It bespeaks years of work dedicated to field of legal informatics. Yet, it also shows that he has a profound knowledge of - and indeed contributed to the creation of - general doctrines (Allgemeine Lehren) in our discipline. He has not specialized excessively. He is not a narrow scope specialist. And he has a talent for asking the right questions. From information retrieval dealing with mere documents, ERICH has progressed to the era of information management and now speaks of legal data science. ${ }^{35}$ Once again, legal informatics is called upon to take on new, important practical dimensions. At the same time, we see general doctrines assuming greater significance. This development merits closer attention, also in the training of lawyers. We are on the same right road.

\section{REFERENCES}

AsIMOV, ISAAC The next seventy years for law and lawyers. American Bar Association Journal 71:57-59 (1985).

ChARles P. BouRnE and TRUdi Bellardo HAHN wrote 2003: «..the world of computer-based information storage and retrieval and broadband communication technology is changing too fast and heading in unimaginable directions. Every day a new story is just around the corner». BouRNE BELLARDO HAHN A history of Online information Services. $p$ 410. That is true if we do not have general theories and if we do not have common metadata and if we do not follow standardized markup language solutions like Akoma Ntoso.

35 See more SCHWEIGHOFER The Role of AI \& Law in Legal Data Science. 
BING, JON Rettslige kommunikasjonsprosesser: bidrag till en generell teori NORIS (30) Publications of the Norwegian Research Center for Computers and Law, no. 11. (1982).

Blume, Peter Fra tale til data. Studier I det juridiske informationssystem, København (1984).

Blume, Peter Retssystemet og Juridisk Metode 3rd ed København (2016).

Bourne, Charles P - Bellardo Hahn, TRudi A history of online Information Services 1963-1976, MIT 2003.

Dingledy, Frederick W. From Stele to Silicon: Publication of Statutes, Public Access to the Law, and the Uniform Electronic Legal Material Act in Law Library Journal Vol. 111:2 [2019-9].

FRANKENREITER, JENS Writing style and legal traditions pp. 153-191 in LIVERMORE - ROCKMORE (eds) Law as Data.

GREENLEAF, GRAHAM Jon Bing and the History of Computerised Legal Research - Some Missing Links in TORVUND - BYGRAVE (eds) Et tilbakeblikk på fremtiden Et Tilbakeblikk på fremtiden: artikler samlet i anledning Jon Bings 6o-årsdag 30. april 2004, Institutt for rettsinformatikk Oslo.

Livermore Michael A. - Rockmore, Daniel N.(eds) Law as Data, Computation, Text, \& the future of Legal Analysis The Santa Fe institute Press (2019).

LIEBWALD, DORIS On transparent law, good legislation and accessibility to legal information: Towards an integrated legal information system, Artif Intell Law (2015) 23:301314 .

LuOSTARINEn, HeikKI - VÄLIVERRONEn, EsA Tekstinsyöjät. Yhteiskuntatieteellisen kirjallisuuden lukutaidosta. Vastapaino. Tampere (1991).

Magnusson-SJÖBerg, Cecilia Critical Factors in Legal Document Management: A study of Standardised Markup Languages, Jure (1998).

MAGNUSSON-SJÖBERG, CECILIA XML as a tool for legal validity in a security context, SLIM Paper 2002:1. 
MAHLER, TOBIAS Tool-supported Legal Risk Management: A Roadmap, European Journal of Legal Studies, 2010.

MatTila, HeikKi E.S. Comparative Legal Linguistics, 2nd ed, Ashgate 2013.

MÄKINEN ILKKA (ed) Tiedon tie; johdatus informaatiotutkimukseen, BTJ-kustannus 11 ed (2007) in Finnish.

NiEMI, MARJA-LEENA (ed) Oikeus tänään (Law today) 3rd ed, University of Lapland 2015.

Palmirani, MonicA - Vitali, FAbio Akoma-Ntoso for legal documents pp. 75-10o in Legislative XML.

Peruginelli, Ginerva - Faro, Sebastiano (eds) Knowledge of The Law in the Big Data Age, IOS Press (2019).

Oksanen Arttu, Tamper Minna, TuOminen Jouni, MäKelä Eetu, Hietanen Aki, Hyvönen EERO Semantic Finlex: Transforming, Publishing, and Using Finnish Legislation and Case Law As Linked Open Data on the Web p. 212-228.

SAARENPÄÄ AHTI, Henkilö- ja persoonallisuusoikeus pp. 203-428 in NIEMI (ed) Oikeus tänään (2015) in Finnish.

SAARENPÄÄ, AHTI The Digital Lawyer. What skills are required of the lawyer in the Network Society? pp. 73-85 in SCHWEIGHOFER - KUMMER - HÖTZENDORFER (eds) Kooperation - Cooperation, IRIS 2015 Österreichische Computer Gesellschaft - Austrian Computer Society (2015).

SAARENPÄÄ, AHTI The Network Society and Legal Information, Some observations from the Nordic point of view. Law via the Internet conference papers 2011 in address http://www.hklii.hk/conference/paper/2D1.pdf.

SAARENPÄÄ, AHTI Does Legal Informatics Have A Method in the New Network Society? p. 68. in SAARENPÄÄ-WIATROWSKI, (eds) Society Trapped in the Network. Does it have a Future?

SAARENPÄÄ, Ahti - Wiatrowski, AleKSANDER (eds) Society Trapped in the Network. Does it have a Future? University of Lapland (2016) http://urn.fi/URN: ISBN:978-952-484-917-3. 
SARTOR, G., Palmirani, L., Francesconi, E., BiAsiotti, M.A. (eds). Legislative XML for the Semantic Web, Springer (2011).

SHAW JULIA J. A. Worth a Thousand Words: The Unwritten History of Law as a Jurisprudence of Text and Pictures, International Journal for the Semiotics of Law (2019) 32:753-758.

SCHWEIGHOFER, ERICH Wissensrepräsentation und automatische Textanalyse im Völkerund Europarecht, Habilitationsschrift, Universität Wien 1996; in english Legal Knowledge Representation, Automatic Text Analysis in Public International and European Law, Kluwer Law International, Law and Electronic Commerce, Volume 7, The Hague (1999).

SCHWEIGHOFER, ERICH: From information retrieval and artificial intelligence to legal data science. In: Schweighofer, E., Galindo, F., Cerbena, C. (eds.), Proceedings of MWAIL 2015, ICAIL Multilingual Workshop on AI \& Law Research, held Within the 15th International Conference on Artificial Intelligence \& Law (ICAIL 2015), pp. 13-23. OCG, Vienna (2015).

SCHWEIGHOFER, ERICH - PreISS, ThOMAS Risikoanalyse im Recht - eine neue juristische Methodik? In: MAYR, H. C. \& PINZGER, M. (Hrsg.), Informatik 2016. Bonn: Gesellschaft für Informatik e.V. (pp. 597-6o8).

SCHWEIGHOFER, ERICH The Role of AI \& Law in Legal Data Science pp. 191-192 in Volume 279: Legal Knowledge and Information Systems, IOS press ebooks 2015.

SEIPEL, PETER Juristen och datorn: introduktion till rättsinformatiken Norstedts 1990. 3. ed.

TALUS, Anu From simply sharing the cage to living together reconciling the right of public access to documents with the protection of personal data in the European legal framework, Unigrafia Helsinki 2019

WAHLgren, Peter Legal Risk Analysis - A Proactive Legal Method, Jure 2013.

WIKSTRÖM, KAUKO Kuka tarvitsee oikeuslähdeoppia? (Who does need the Theory of Legal Sources, (in Finnish) in Oikeus - kulttuuria ja teoriaa (Law as culture and theory (2007): pp. 271-286. 